\title{
Comparative performance of empirical methods to estimate the reference evapotranspiration in Aquidauana, MS, Brazil
}

\section{Comparação do desempenho de métodos para a estimativa da evapotranspiração de referência, em Aquidauana-MS}

\author{
Taynara da Silva MORAES ${ }^{1}$; Adriano da Silva LOPES $^{2}$; Eder Duarte FANAYA JÚNIOR ${ }^{3}$; \\ Vitor Gabriel Marinho de Faria PEREIRA ${ }^{4}$; Carla Deisiane de Oliveira COSTA ${ }^{5}$; Uilhiam CHERRI ${ }^{6}$ \\ ${ }^{1}$ Graduação em Engenharia Florestal pela Universidade Estadual de Mato Grosso do Sul - UEMS. E-mail: \\ tay_moraes123@hotmail.com \\ ${ }^{2}$ Prof. Dr. Adjunto da Universidade Estadual de Mato Grosso do Sul - UEMS. E-mail: lopes@uems.br \\ ${ }^{3}$ Doutorando do programa de pós-graduação em Engenharia de Sistemas Agrícolas, departamento de Engenharia de \\ Biossistemas. Escola Superior em Agricultura "Luiz de Queiroz", ESALQ/USP. E-mail: eder.fanayajr@usp.br \\ ${ }^{4}$ Mestrado em Produção vegetal pela Universidade Estadual de Mato Grosso do Sul - UEMS. E-mail: \\ vitor_gmfp@hotmail.com \\ ${ }^{5}$ Autor para correspondência: Pós doutoranda do programa de pós-graduação em Produção Vegetal pela Universidade \\ Estadual de Mato Grosso do Sul - UEMS. E-mail: carladeisiane@uems.br \\ ${ }^{6}$ Graduação em Engenharia Florestal pela Universidade Estadual de Mato Grosso do Sul - UEMS. E-mail: \\ uilhiamcherri@gmail.com
}

Recebido em: 28-03-2017; Aceito em: 21-02-2018

\begin{abstract}
Estimating the reference evapotranspiration is quite useful when managing irrigation, as before picking the right method; it is necessary to analyse local's climatic conditions. Therefore, the aim of this study was to evaluate the performance of empirical methods to estimate $\mathrm{ET}_{0}$, comparing them with $\mathrm{FAO}$ reference evapotranspiration from Penman-Monteith equation, for the region of Aquidauana, Brazil. The empirical methods used were Camargo (CM), Hargreaves-Samani (HS), Jensen-Haise (JH) and Priestley \& Taylor (PT). The climatic variables were obtained from a station of the National Institute of Meteorology (INMET), located in Aquidauana, MS, collected between January of 2008 and December of 2014. In order to compare the values of ETo obtained from the empirical equations with the standard method of Penman-Monteith, it was considered the following parameters: regression equation ( $a$ and $b$ ), coefficient of determination $\left(R^{2}\right)$, Willmott's index $(d)$ and C-index $(c)$, as both for dry and rainy period. The method of Priestley \& Taylor was the one that presented the closest value to PenmanMonteith equation, followed by the method of Jensen-Haise. The methods of Hargreaves-Samani and Camargo are not recommended to the region of Aquidauana, MS.
\end{abstract}

Additional keywords: climatic elements; irrigation management; Penman-Monteith equation.

\section{Resumo}

Estimar a evapotranspiração de referência (ETo) é bastante útil para o manejo da irrigação, pois para selecionar o melhor método a ser utilizado é necessário analisar as variáveis climáticas disponíveis no local. O objetivo deste trabalho foi avaliar o desempenho dos métodos empíricos para estimativa da $\mathrm{ET}_{0}$, comparando com o métodopadrão de Penman-Monteith, para a região de Aquidauana-MS. Os métodos de análise utilizados foram: Camargo (CM), Hargreaves-Samani (HS), Jensen-Haise (JH), Priestley \& Taylor (PT), e as variáveis climáticas foram obtidas na rede de estações do Instituto Nacional de Meteorologia (INMET), situado em Aquidauana-MS, entre janeiro de 2008 e dezembro de 2014. Para se comparar os valores de ET 0 estimados por meio das equações empíricas com os do método-padrão, foram considerados os seguintes parâmetros: equação de regressão ( $a$ e b), coeficiente de determinação $\left(r^{2}\right)$, índice de concordância (d) e o índice de desempenho (c), tanto para o período seco como para o chuvoso. O método de Priestley \& Taylor obteve o valor mais próximo do métodopadrão de Penman-Monteith dentre os analisados neste trabalho, sendo seguido pelo Jensen-Haise. Os métodos de Hargreaves-Samani e Camargo são desaconselhados para a região de Aquidauana-MS.

Palavras-chave adicionais: elementos climáticos; manejo de irrigação; Penman-Monteith.

\section{Introduction}

The hydrological cycle consists in a constant water exchange between the ground surface and the atmosphere. The surface evapotranspiration is defined according to Araujo et al. (2011) as the amount of wa- ter loss evaporated and transpirated from a surface covered by vegetation during any period of time.

The reference evapotranspiration $\left(\mathrm{ET}_{0}\right)$ is an important meteorological parameter, not only as a climatic element of water demand used for meteorological studies, but also an important tool for the agri- 
culture, especially when managing irrigation supply (Carvalho et al., 2011).

According to Pereira et al. (2002), ETo is the amount of water that would be used by a surface covered by a 8 to $15 \mathrm{~cm}$ tall grass vegetation in active growth, fully covering the ground surface and with no lack of water.

There are many methods to estimate $\mathrm{ET}_{0}$, ranging from empirical ones which are the simplest to those filled with more scientific basement. This diversity of methods is due to the response of water transference in the soil-plant-atmosphere system under different edaphoclimatic conditions (Carvalho et al., 2011). As the empirical methods use data from local meteorological stations, they are set to better suit the study model in some cases (Pereira et al., 2002).

Among all methods to estimate $\mathrm{ET}_{0}$, the Penman-Monteith equation is recommended by FAO as the standard method for the estimative of $\mathrm{ET}_{0}$, as well as, when calibrating empirical methods due to present great performance even when applied in different climatic conditions. However, due to require plenty of climatic data, the use of the FAO method may not be possible in certain locations (Palaretti et al., 2014).

Therefore, before picking the right method to estimate $E T_{0}$, it is necessary to know which climatic elements are available as the use of a certain method is totally dependent on them availability (Araujo et al., 2007).

The use of empirical methods throughout available climatic data can be an alternative to local farmers when growing crops under irrigation supply. Thus, the aim of this study was to evaluate the performance of empirical methods to estimate $E T_{0}$ for the region of Aquidauana, State of Mato Grosso do Sul, Brazil.

\section{Material and methods}

The climatic data was collected between $1^{\text {st }}$ January of 2008 and $31^{\text {st }}$ December of 2014, and it was obtained from the National Institute of Meteorology (INMET), located in Aquidauana in the coordinates $20^{\circ} 20^{\prime} 8^{\prime \prime} \mathrm{S}$ and $55^{\circ} 48^{\prime} 15^{\prime \prime} \mathrm{W}$ with average elevation of $191 \mathrm{~m}$. The region climate is classified according to Köppen as Aw, tropical sub-humid with an average annual precipitation of $1231 \mathrm{~mm}$.

It was used climatic data daily collected, such as air temperature $\left({ }^{\circ} \mathrm{C}\right)$, relative air humidity $(\%)$, wind speed at $2 \mathrm{~m}$ above soil surface $\left(\mathrm{m} \mathrm{s}^{-1}\right)$ and average solar radiation $\left(\mathrm{MJ} \mathrm{m}^{2}\right.$ day $\left.^{-1}\right)$. The data was then divided in two seasonal periods, rainy (October to March) and dry (April to September).

In order to estimate $\mathrm{ET}_{0}$, the following methods were tested and compared to the Penman-Monteith equation: Camargo, Hargreaves-Samani, JensenHaise, and Priestley \& Taylor.

\section{Penman-Monteith Method (PM)}

Recommended by FAO as the standard method, the Penmam-Monteith equation (equation 1) considers some constant parameters, such as grass height set in $0.12 \mathrm{~m}$ from the surface, stomatal resistance of $70 \mathrm{~s} \mathrm{~m}^{-1}$ and albedo of 0.23 . The value of heat flow in the soil was considered zero (Allen et al., 1998). The following equation below shows the method.

$\mathrm{ET}_{0} \mathrm{PM}=\frac{0.408 \Delta\left(\mathrm{R}_{\mathrm{n}}-\mathrm{G}\right)+\gamma \frac{900}{\mathrm{~T}_{\mathrm{med}}+273.16} \mathrm{U}_{2}\left(\mathrm{e}_{\mathrm{s}}-\mathrm{e}_{\mathrm{a}}\right)}{\Delta+\gamma\left(1+0.34 \mathrm{U}_{2}\right)}$

Wherein: $E T_{0} P M$ is the reference evapotranspiration according to Penman-Monteith method $\left(\mathrm{mm} \mathrm{d}^{-1}\right), \Delta$ is the declination of the curve of water vapour saturation $\left(\mathrm{kPa}{ }^{\circ} \mathrm{C}^{-1}\right), \mathrm{R}_{\mathrm{n}}$ is the radiation balance $\left(\mathrm{MJ} \mathrm{m}^{-2} \mathrm{~d}^{-1}\right), \mathrm{G}$ is the soil heat flow $\left(\mathrm{MJ} \mathrm{m}^{-2} \mathrm{~d}^{-1}\right), \gamma$ is the psychrometric constant $\left(\mathrm{kPa}{ }^{\circ} \mathrm{C}^{-1}\right), \mathrm{U}_{2}$ is the average wind speed at 2 $\mathrm{m}$ above the soil surface $\left(\mathrm{m} \mathrm{s}^{-1}\right), T_{\text {med }}$ is the average air temperature $\left({ }^{\circ} \mathrm{C}\right), \mathrm{e}_{\mathrm{s}}$ is the vapour pressure saturation, and $e_{a}$ is the actual vapour pressure $(\mathrm{kPa})$.

\section{Camargo Method (CM)}

Camargo (1971), based on results obtained from the method of Thornthwaite, proposed a method based only on data from average air temperature and extraterrestrial solar radiation shown by equation 2 below.

$$
\mathrm{ET}_{0} \mathrm{CM}=\mathrm{KR}_{\mathrm{a}} \mathrm{T}_{\text {med }} \mathrm{ND}
$$

Wherein: $\mathrm{ET} \mathrm{T}_{0} \mathrm{CM}$ is the reference evapotranspiration according to Camargo method $\left(\mathrm{mm} \mathrm{d}^{-1}\right), R_{a}$ is the incoming extraterrestrial solar radiation above the atmosphere on the $15^{\text {th }}$ day of each month $\left(\mathrm{mm} \mathrm{d}^{-1}\right.$ equivalent evaporation), $\mathrm{T}_{\text {med }}$ is the average daily temperature of period $\left({ }^{\circ} \mathrm{C}\right), \mathrm{ND}$ is the number of days in the observed period, and $\mathrm{K}$ is the adjustment factor.

The adjustment factor $(\mathrm{K})$ varies with the annual average temperature of the place, according to the established limits in Table 1.

\section{Hargreaves-Samani Method (HS)}

This method was developed by Hargreaves \& Samani (1985), in California, USA, under semi-arid conditions where the data was obtained from a lysimeter covered by grass (Pereira et al., 1997) and described according to equation 3 .

$$
E T_{0} H S=0.00135 k t R_{a}\left(T_{\max }-T_{\min }\right)^{0.5}\left(T_{\text {med }}+17.8\right)
$$

Wherein: $E T_{0} H S$ is the reference evapotranspiration according to Hargreaves-Samani $\left(\mathrm{mm} \mathrm{d}^{-1}\right)$, $\mathrm{kt}$ is the coefficient used in continental regions (0.162) (dimensionless), $\mathrm{Ra}$ is the extraterrestrial radiation ( $\mathrm{mm} \mathrm{d}^{-1}$ equivalent evaporation), $\mathrm{T}_{\max }$ is the maximum air temperature $\left({ }^{\circ} \mathrm{C}\right)$, $\mathrm{T}_{\min }$ is the minimum air temperature $\left({ }^{\circ} \mathrm{C}\right)$, Tmed is the average air temperature $\left({ }^{\circ} \mathrm{C}\right)$. 
Table 1 - Adjustment factor value $(K)$ in relation to the annual average temperature.

\begin{tabular}{lcccccc}
\hline $\mathrm{Ta}\left({ }^{\circ} \mathrm{C}\right)$ & $<23.5$ & 23.6 to 24.5 & 24.6 to 25.5 & 25.6 to 26.5 & 26.6 to 27.5 & $>27,5$ \\
\hline $\mathrm{K}$ Value & 0.01 & 0.0105 & 0.011 & 0.0115 & 0.012 & 0.013 \\
\hline
\end{tabular}

According to Camargo \& Camargo (2000).

\section{Jensen-Haise Method (JH)}

Jensen and Haise developed equation (4) to estimate $\mathrm{ET}_{0}$ in arid regions (Pereira et al., 1997).

$$
\mathrm{ET}_{0} \mathrm{JH}=\mathrm{R}_{\mathrm{s}}\left(0.025 \mathrm{~T}_{\text {med }}+0.08\right)
$$

Wherein: $E T_{0} \mathrm{JH}$ is the reference evapotranspiration according to Jensen-Haise method $\left(\mathrm{mm} \mathrm{d}^{-1}\right)$, Rs is the solar radiation converted into units of evaporated water $\left(\mathrm{mm} \mathrm{d}^{-1}\right), T_{\text {med }}$ is the average daily air temperature $\left({ }^{\circ} \mathrm{C}\right)$.

\section{Priestley \& Taylor Method (PT)}

This method is also used in to estimate $\mathrm{ET}_{0}$ as it is quite similar to the method of Penman-Monteith. In the Priestley \& Taylor equation (5), the balance of radiation is corrected by an empirical coefficient " $\alpha$ ", known as a parameter of Priestley \& Taylor (1972), which incorporates the additional energy to the process of evapotranspiration coming from the aerodynamic term.

$$
\mathrm{ET}_{0} \mathrm{PT}=\frac{\alpha \frac{(\Delta+\gamma)}{\gamma}\left(\mathrm{R}_{\mathrm{n}}-\mathrm{G}\right)}{\lambda}
$$

Wherein: EToPT is the reference evapotranspiration according to Priestley \& Taylor method $\left(\mathrm{mm} \mathrm{d}^{-1}\right), \alpha$ is the Priestley \& Taylor parameter (1.26) (dimensionless), $R_{n}$ is the radiation balance (MJ m-2 $\left.\mathrm{d}^{-1}\right), \Delta$ is the declination of the curve of water vapour saturation $\left(\mathrm{kPa}{ }^{\circ} \mathrm{C}^{-1}\right), \gamma$ is the psychrometric constant $\left(\mathrm{kPa}^{\circ} \mathrm{C}^{-1}\right)$, and $\lambda$ is the latent heat flow $\left(2.5 \mathrm{MJ} \mathrm{kg}^{-1}\right)$.

\section{Data analysis}

The performance analysis was run comparing the $E T_{0}$ values obtained by the empirical methods with the Penman-Monteith standard method. Correlation and linear regression analysis were performed to obtain the coefficients of equation $(Y=a+b x)$ and coefficient of determination $\left(R^{2}\right)$. For the accuracy of empirical methods, the statistical analysis was done to determine the concordance index (d) of Willmott et al. (1985), performance index (c), obtained respectively by equations 6 and 7 , and the values of the C-index, interpreted according to Table 2 (Camargo \& Sentelhas, 1997).

$d=1-\frac{\sum_{i=1}^{n}(P i-O i)^{2}}{\sum_{i=1}^{n}(|P i-\bar{O}|+|O i-\bar{O}|)^{2}}$
Wherein: $d$ is the concordance index, $\mathrm{Pi}$ is the values estimated by methods $\left(\mathrm{mm} \mathrm{d}^{-1}\right)$, Oi is the values estimated by the standard method - Penman-Monteith $\left(\mathrm{mm} \mathrm{d}^{-1}\right), \bar{O}$ is the mean values estimated by the standard method $\left(\mathrm{mm} \mathrm{d}^{-1}\right)$.

$C=r d$

Wherein: $C$ is the performance index, $r$ is the correlation coefficient, and $\mathrm{d}$ is the concordance index.

The indication of the best methods to estimate $\mathrm{ET}_{0}$ for the Aquidauana county, MS, Brazil, was carried out according to the criteria proposed by Camargo \& Sentelhas (1997) (Table 2), establishing priority and ascending order for the methods that presented the highest performance index (C), greater than 0.65 .

Table 2 - Interpretation of the performance index (C) to estimate $\mathrm{ET}_{0}$.

\begin{tabular}{cl}
\hline C & Classification \\
\hline$>0.85$ & Great \\
$0.76-0.85$ & Very good \\
$0.66-0.75$ & Good \\
$0.61-0.65$ & Median \\
$0.51-0.60$ & Tolerable \\
$0.41-0.50$ & Bad \\
$\leq 0.40$ & Terrible \\
\hline
\end{tabular}

The validation of the models was obtained according to the mean absolute error (MAE) and root mean square error (RMSE). All statistical calculations were performed with the software Microsoft Office Excelß.

\section{Results and discussion}

The Table 3 shows the averages of the reference evapotranspiration (ETo) for Aquidauana, MS, Brazil, monthly obtained by the methods of Camargo $\left(E T_{0} C M\right)$; Hargreaves-Samani (EToHS); Jensen-Haise $\left(E T_{0} J H\right)$; Priestley \& Taylor $\left(E T_{0} P T\right)$ and PenmanMonteith (EToPM).

Therefore, by the means of daily $\mathrm{ET}_{0}$ data for the dry period (Table 4) and the comparison of the methods evaluated with the standard method, it was observed that among all empirical methods analyzed, the one that presented better performance was the $E T_{0} P T$, with performance index value " $\mathrm{C}$ ", which is classified as very good, presenting correlation coefficient (r) of 0.90 - very strong, performance coefficient (C) of 0.85 and concordance coefficient (d) of 0.949 . 
Table 3 - Averages of reference evapotranspiration (ETo) in Aquidauana, MS, Brazil.

\begin{tabular}{|c|c|c|c|c|c|}
\hline \multirow{2}{*}{ Month } & EToHS & $\mathrm{ET}_{0} \mathrm{CM}$ & EToJH & $\mathrm{ET}_{0} \mathrm{PT}$ & $\mathrm{ET} \mathrm{T}_{0} \mathrm{PM}$ \\
\hline & \multicolumn{4}{|c|}{$\mathrm{mm} \mathrm{d}^{-1}$} & \\
\hline January & 5.51 & 5.01 & 6.72 & 5.53 & 4.86 \\
\hline February & 5.23 & 4.82 & 6.79 & 5.52 & 4.81 \\
\hline March & 4.79 & 4.27 & 6.36 & 5.07 & 4.42 \\
\hline April & 4.14 & 3.45 & 5.09 & 3.96 & 3.60 \\
\hline May & 3.25 & 2.56 & 3.89 & 2.97 & 2.78 \\
\hline June & 2.93 & 2.25 & 3.19 & 2.40 & 2.39 \\
\hline July & 3.30 & 2.35 & 3.90 & 2.81 & 2.89 \\
\hline August & 4.25 & 2.93 & 4.43 & 3.36 & 3.62 \\
\hline September & 4.99 & 3.83 & 5.47 & 4.21 & 4.53 \\
\hline October & 5.47 & 4.55 & 6.18 & 4.96 & 4.79 \\
\hline November & 5.75 & 4.91 & 6.97 & 5.66 & 5.11 \\
\hline December & 5.79 & 5.19 & 7.59 & 6.12 & 5.44 \\
\hline Mean & 4.62 & 3.84 & 5.55 & 4.38 & 4.10 \\
\hline MI-PM ${ }^{*}$ & 0.52 & -0.26 & 1.45 & 0.28 & - \\
\hline
\end{tabular}

MI-PM: Difference between the means of reference evapotranspiration of empirical methods with the mean of the Penman-Monteith standard method of FAO-56.

Table 4 - The performance of empirical methods to estimate daily ET 0 during dry period, between 2008 and 2014 in Aquidauana, MS, Brazil.

\begin{tabular}{lcccl}
\hline Methods & d & R & C & Performance \\
\hline CM & 0.720 & 0.686 & 0.494 & Bad \\
HS & 0.828 & 0.783 & 0.648 & Median \\
JH & 0.811 & 0.913 & 0.741 & Good \\
PT & 0.949 & 0.904 & 0.858 & Very good \\
\hline
\end{tabular}

CM: Camargo method; HS: Hargreaves-Samani method; JH: Jensen-Haise method; PT: Priestley \& Taylor method; r: correlation coefficient; d: concordance coefficient; C: performance coefficient.

Then, the method that presented satisfactory performance index was $\mathrm{ET}_{0} \mathrm{JH}$ with good performance, presenting values of $r, C$ and $d$ equal to 0.91 - very strong, 0.74 and 0.811 , respectively. The $\mathrm{ET}_{\mathrm{O}} \mathrm{HS}$ and EToCM methods presented average and bad performance. It was found low values of $r, C$ and $d$ coefficient for $\mathrm{ET}_{0} \mathrm{CM}$ method with $0.68,0.49$ and 0.720 , respectively.

For the regression parameters (Figure 1),

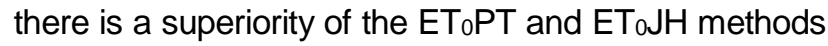
compared to the others, with determination coefficient value $\left(R^{2}\right)$ of 0.8170 and 0.8343 , respectively (Figures $1 \mathrm{D}$ and $1 \mathrm{C}$ ). Thus, in this parameter as in the other coefficients, the closer to the unit, the closer is the method to the standard one.

The figure 1D shows that the Priestley and Taylor's trend line almost overlapped the tendency line of the standard method, giving therefore a good adjustment. On the other hand, in the others methods, such as $E T_{0} H S$ and $E T_{0} C M$, it was observed low values of $R^{2}, 0.6124$ and 0.4701 , respectively, indicating lack of adjustment for the region of Aquidauana.
According to the results observed in Table 5 for rainy period, the methods that presented the best adjustments were $\mathrm{ET}_{0} \mathrm{PT}$ and $\mathrm{ET} \mathrm{T}_{0} \mathrm{JH}$, being classified as "Great" by performance coefficient (C), obtaining values of 0.95 and 0.94 , respectively. In addition, they also presented the highest values in the correlation coefficient (r), 0.95 for EToPT and 0.97 for EToJH, indicating strong correlation with the standard method.

Table 5 - The performance of empirical methods to estimate the daily $\mathrm{ET}_{0}$ during rainy period, between 2008 and 2014 in Aquidauana, MS, Brazil.

\begin{tabular}{ccccc}
\hline Methods & $\mathrm{d}$ & $\mathrm{r}$ & $\mathrm{C}$ & Performance \\
\hline CM & 0.984 & 0.473 & 0.466 & Bad \\
HS & 0.988 & 0.659 & 0.652 & Median \\
JH & 0.970 & 0.971 & 0.942 & Great \\
PT & 0.995 & 0.957 & 0.952 & Great \\
\hline
\end{tabular}

CM: Camargo method; HS: Hargreaves-Samani method; JH: Jensen-Haise method; PT: Priestley \& Taylor method; $r$ : correlation coefficient; $d$ : concordance coefficient; C: performance coefficient. 

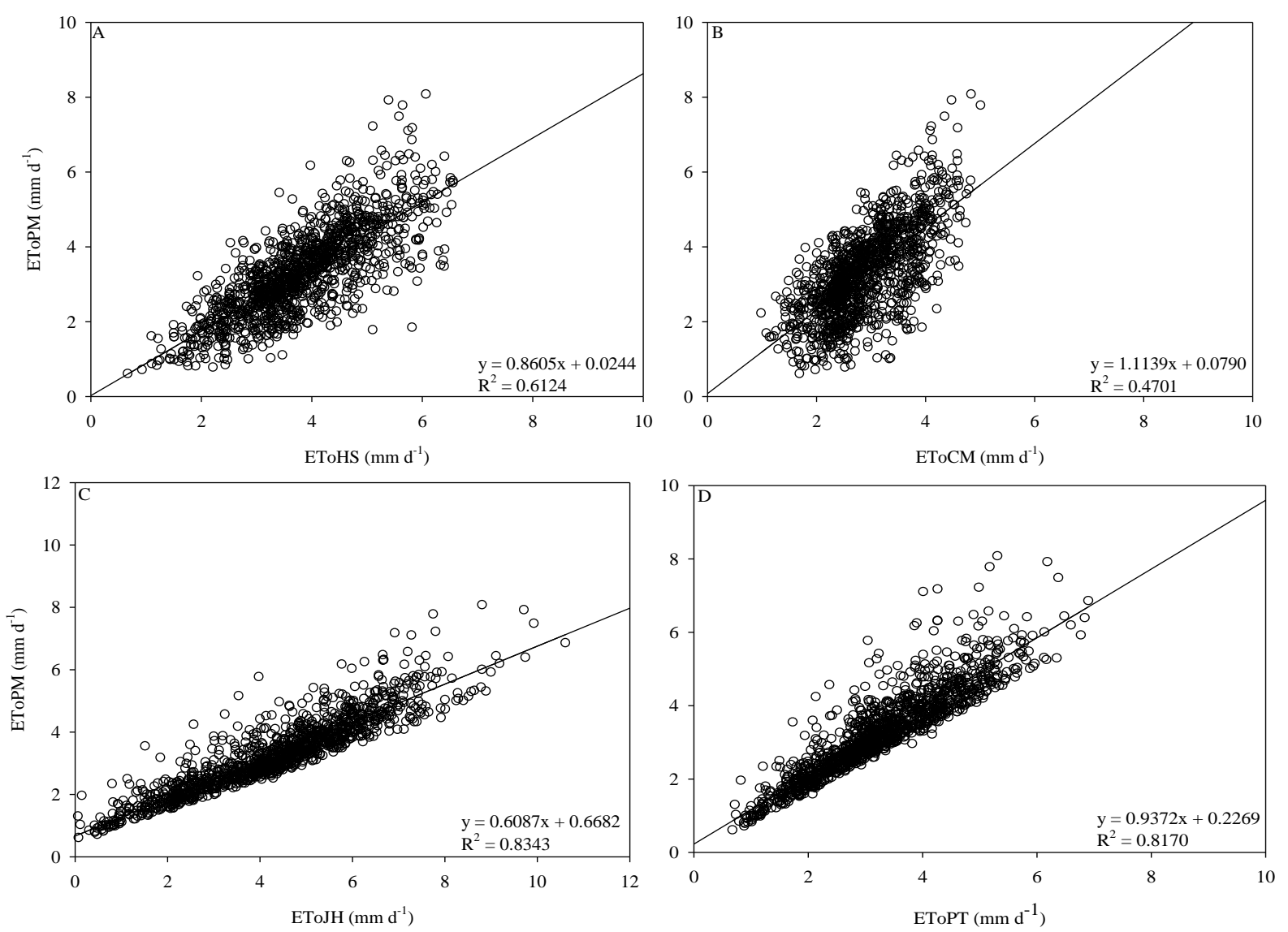

Figure 1 - Linear regression between daily values of reference evapotranspiration (ETo) during dry period, estimated by comparing the empirical methods of Hargreaves-Samani (A), Camargo (B), Jensen-Haise (C), and Priestley \& Taylor (D) to the standard method of Penman-Monteith, between 2008 and 2014 in Aquidauana, MS, Brazil.

According to the results presented in the Table 5, only $\mathrm{ET}_{0} \mathrm{HS}$ and $\mathrm{ET}_{0} \mathrm{CM}$ methods are not recommended to the region of Aquidauana, MS, Brazil, for presenting performance index (c) below 0.65 (Camargo \& Sentelhas, 1997). Also, presenting low values of correlation coefficient $(r)$ indicates low correlation with the standard method.

In the rainy period the methods ETOPT and $E T_{0} \mathrm{JH}$ presented better performances in comparison to the other empirical methods (Figure 2), with determination coefficient values $\left(R^{2}\right)$ of 0.9154 and 0.9428 , respectively (Figures $2 \mathrm{D}$ e $2 \mathrm{C}$ ), presenting better adjustment than in the dry period.

The EToCM was the only method that showed an angular coefficient above 1 and also a low value of determination coefficient $\left(R^{2}\right)$ in the two seasonal periods (Figure 1) and (Figure 2). In all the parameters analyzed, there is a lower performance for the Camargo method when estimating $\mathrm{ET}_{0}$ in the region of Aquidauana.

Souza et al. (2014) found similar results in the region of Santa Tereza, ES, Brazil, where Priestley and Taylor method presented better evaluation when compared to the standard method in the two periods, dry and rainy. They also observed that the Camargo method obtained a lower classification when estimating $\mathrm{ET}_{0}$.
Borges Júnior et al. (2012) also observed a result quite close to the Penman-Monteith when using the method of Priestley \& Taylor in the seasonal periods of spring-summer and autumn-winter. The empirical method provided high values of correlation coefficient $(0.92$ and 0.97$)$ and reliability index $(0.87$ and 0.93), which indicates "great" performance for the Garanhuns micro-region, PE, Brazil, in the Southern Agreste Pernambucano. Fietz \& Fisch (2008) claimed "very good" performance of this method in the region of Dourados, MS, Brazil.

In relation to cumulative and absolute frequency compared to the relative error, the Priestley and Taylor $\left(E T_{0} P T\right)$ and Jensen-Haise $\left(E T_{0} \mathrm{JH}\right)$ methods presented better results, with lower values of percentage relative error (Figure 3 ).

According to Tanaka et al. (2016), the mean absolute error (MAE) indicator represents the deviation of the averages and provides information about the performance of the model. Thus, in the rainy period (Figure 4A), the $\mathrm{ET}_{0} \mathrm{HS}$ and $\mathrm{ET}_{0} \mathrm{JH}$ methods underestimated the pattern. On the other hand, the $\mathrm{ET}_{0} \mathrm{CM}$ and EToPT methods overestimated the standard method, presenting better performance. For the dry period, the $\mathrm{ET}_{0} \mathrm{HG}, \mathrm{ET}_{0} \mathrm{JH}$ and $\mathrm{ET}_{0} \mathrm{PT}$ methods underestimated while the $\mathrm{ET}_{0} \mathrm{CM}$ method overestimated the standard method of Penman-Monteith. 
Similarly, the smaller the value of the statistical indicator square root of the root square mean error (RMSE), the better is the performance of the model tested. Both for rainy (Figure 5A) and dry period
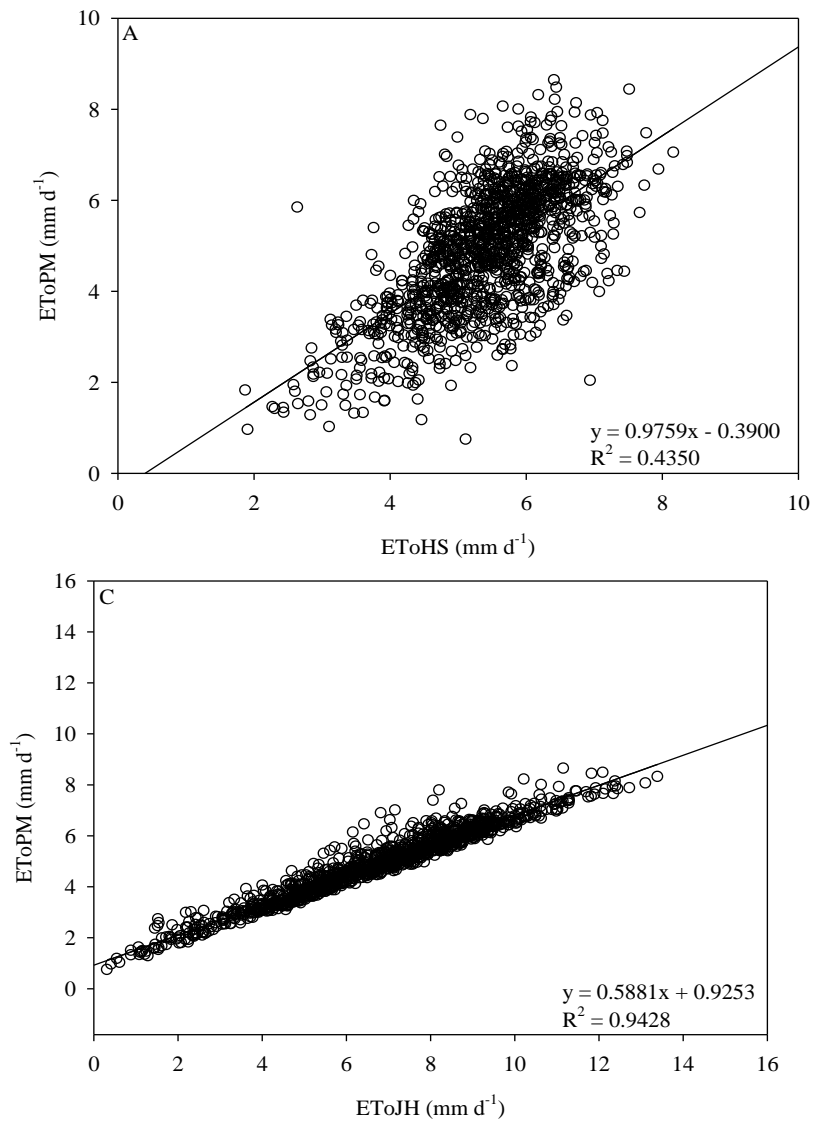

(Figure 5B), the EToPT method was the one that presented the best performance.
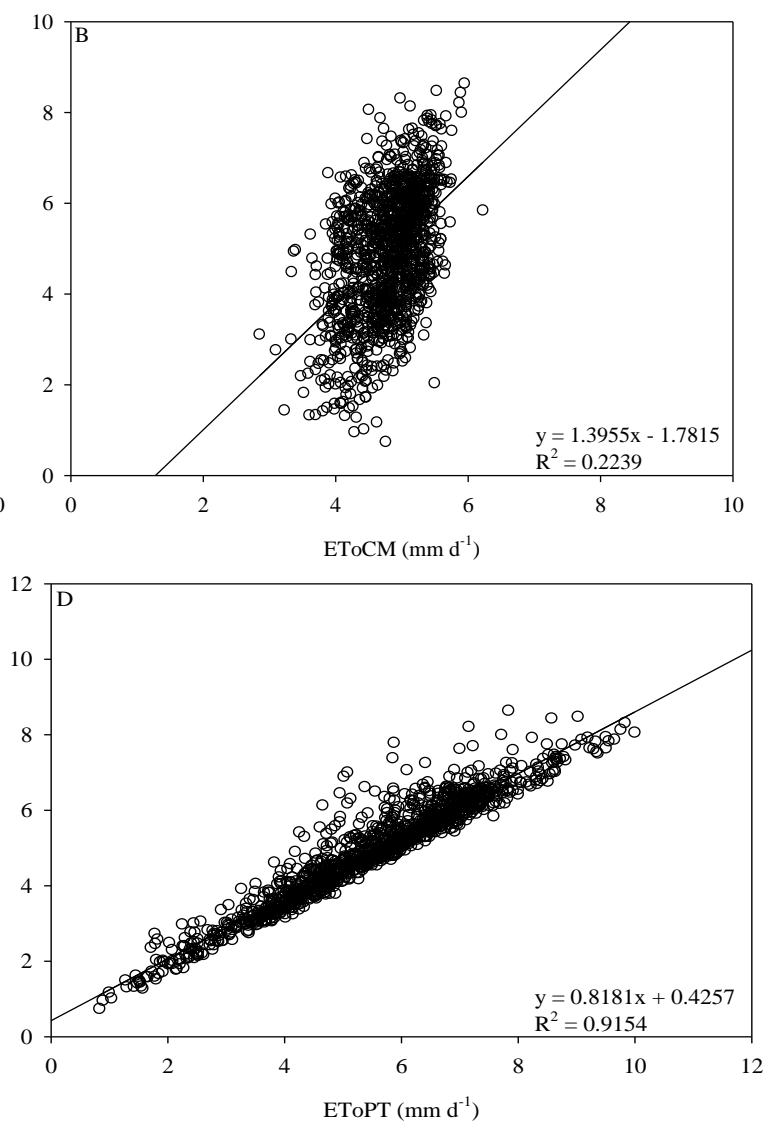

Figure 2 - Linear regression between daily values of reference evapotranspiration $\left(E T_{0}\right)$ in the rainy period, estimated by comparing the empirical methods of Hargreaves-Samani (A), Camargo (B), Jensen-Haise (C), and Priestley \& Taylor (D) to the standard method of Penman-Monteith, between 2008 and 2014 in Aquidauana, MS, Brazil.
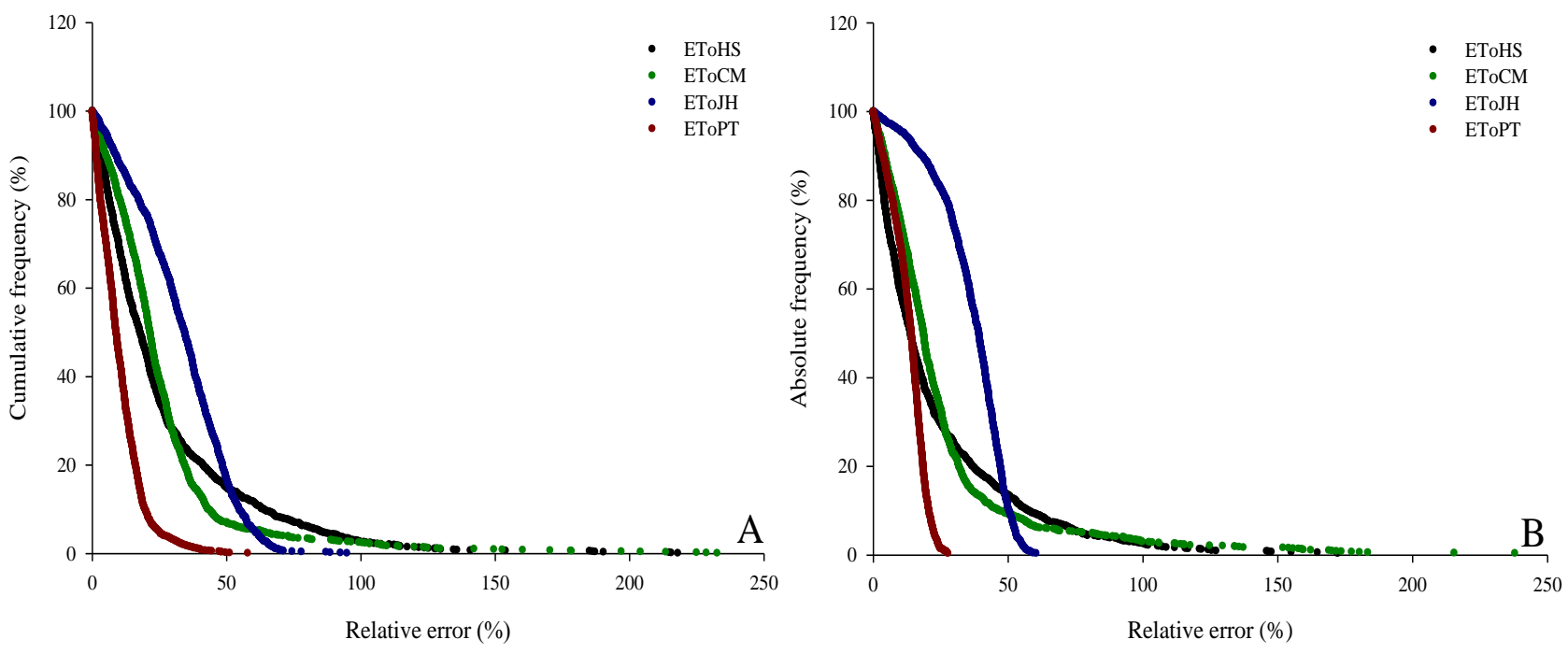

Figure 3 - Cumulative and absolute frequency and relative error of the methods of Hargreaves-Samani (EToHS), Camargo $\left(E T_{0} C M\right)$, Jensen-Haise $\left(E T_{0} J H\right)$, and Priestley \& Taylor $\left(E T_{0} P T\right)$, in dry and rainy periods in Aquidauana, MS, Brazil. 

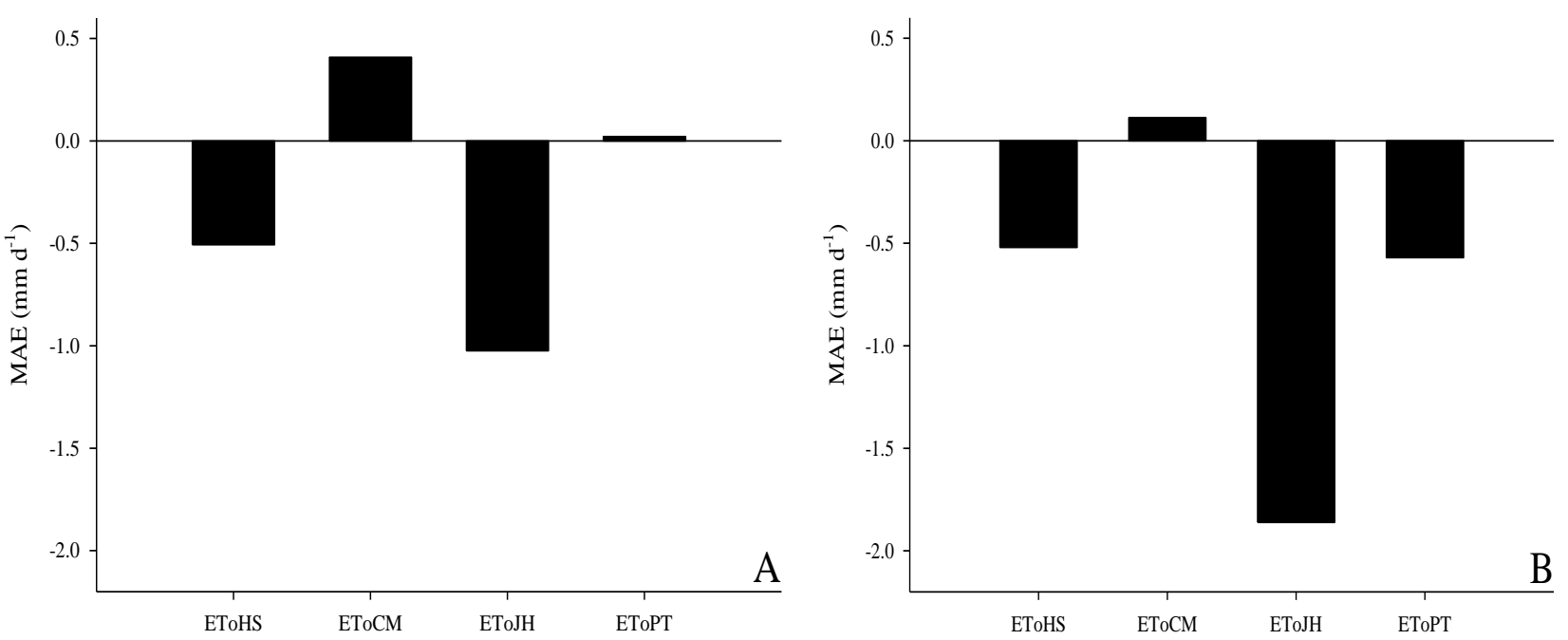

Figure 4 - Mean absolute error (MAE) $\left(\mathrm{mm} \mathrm{d}^{-1}\right)$ of rainy $(A)$ and dry periods $(B)$, estimated by comparing the empirical methods of Hargreaves-Samani $\left(E T_{0} H S\right)$, Camargo $\left(E T_{0} C M\right)$, Jensen-Haise $\left(E T_{0} J H\right)$, and Priestley \& Taylor (EToPT) to the standard method of Penman-Monteith, between 2008 and 2014 in Aquidauana, MS, Brazil.
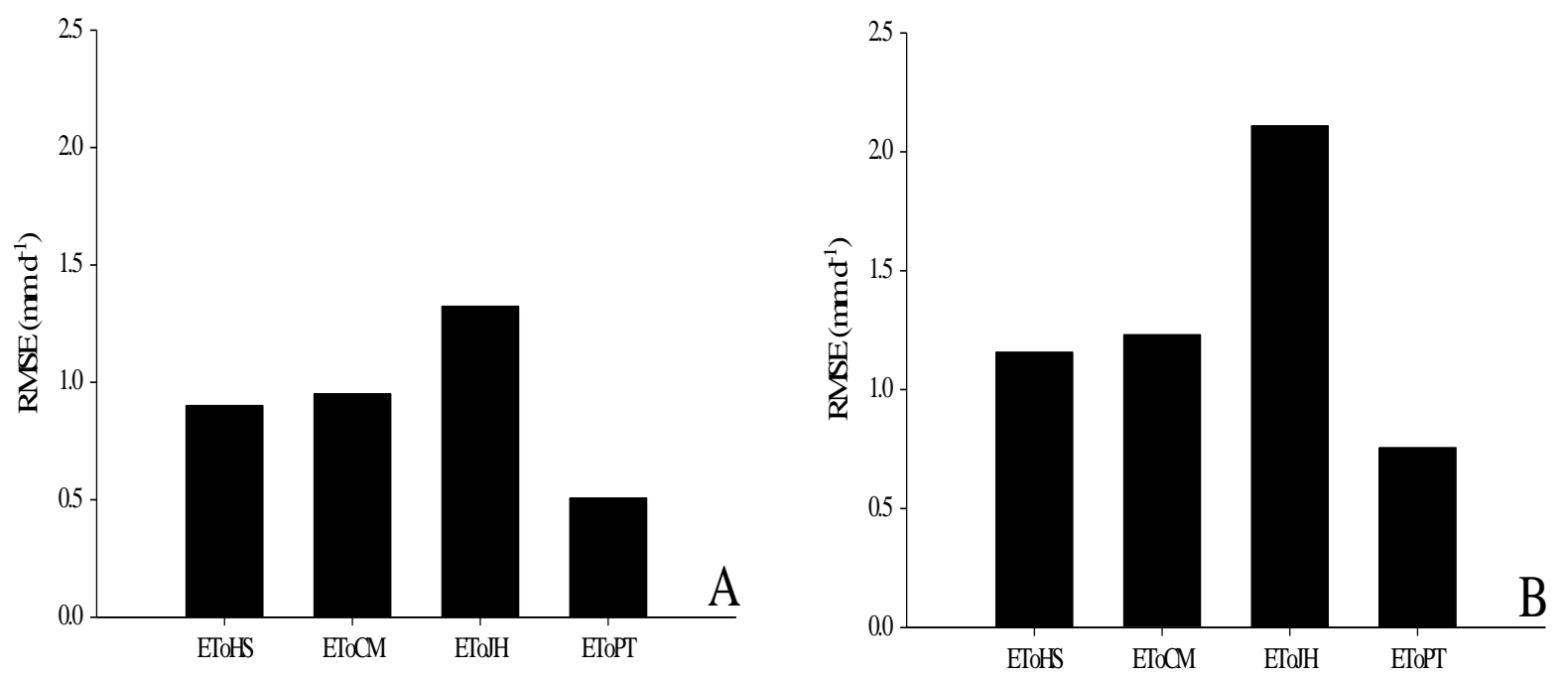

Figure 5 - Root mean square error (RMSE) $\left(\mathrm{mm} \mathrm{d}^{-1}\right)$ of rainy $(A)$ and dry periods $(B)$, estimated by comparing the empirical methods of Hargreaves-Samani $\left(E T_{0} H S\right)$, Camargo $\left(E T_{0} C M\right)$, Jensen-Haise $\left(E T_{0} J H\right)$, and Priestley \& Taylor (EToPT) to the standard method of Penman-Monteith, between 2008 and 2014 in Aquidauana, MS, Brazil.

Thus of all parameters evaluated, the Priestley and Taylor $\left(\mathrm{ET} \mathrm{P}_{\mathrm{PT}}\right)$ and Jensen-Haise $\left(\mathrm{ET} \mathrm{T}_{0} \mathrm{JH}\right)$ methods presented the best performance for the estimate of reference evapotranspiration for the region of Aquidauana, MS, Brazil.

\section{Conclusion}

The Priestley \& Taylor and Jensen-Haise methods are recommended to estimate the reference evapotranspiration $\left(E T_{0}\right)$, for being the methods that most approached to the standard method in the dry (April to September) and rainy (October to March) periods in Aquidauana, MS, Brazil. The methods $\mathrm{ET}_{0} \mathrm{HS}$ and $\mathrm{ET}_{0} \mathrm{CM}$ are not recommended for the region of Aquidauana, MS, Brazil for presenting low performance index.

\section{References}

Allen RG, Pereira LS, Raes D, Smith M (1998). Crop Evapotranspiration: guidelines for computing crop requirements. FAO. 301p.

Araujo WF, Costa SAA, Santos AE (2007). Comparação entre métodos de estimativa da evapotranspiração de referência $\left(E T_{0}\right)$ para Boa Vista, RR. Caatinga 20:84-88.

Araujo G, Reis EF, Martins CA, Barbosa VN, Rodrigues RR (2011). Desempenho comparativo de métodos para a estimativa da evapotranspiração de referência $\left(E T_{0}\right)$. Revista Brasileira de Agricultura Irrigada 5:84-95. 
Borges Júnior JCF, Anjos RJ, Silva TJA., Lima JRS, Andrade CLT (2012). Métodos de estimativa da evapotranspiração de referência diária para a microrregião de Garanhuns, PE. Revista Brasileira de Engenharia Agrícola e Ambiental 16:380-390.

Camargo AP (1971). Balanço hídrico no Estado de São Paulo. 3.ed. Instituto Agronômico. 24p.

Camargo AP, Camargo MBP (2000). Uma revisão analítica da evapotranspiração potencial. Bragantia 59:125-137.

Camargo AP, Sentelhas PC (1997). Avaliação do desempenho de diferentes métodos de estimativa da evapotranspiração potencial no Estado de São Paulo, Brasil. Revista Brasileira de Agrometeorologia 5:89-97.

Carvalho LG, Rios GFA, Miranda WL, Castro Neto P (2011). Evapotranspiração de referência: Uma abordagem atual de diferentes métodos de estimativa. Pesquisa Agropecuária Tropical 41:456-465.

Fietz CR, Fisch GF (2008). O clima da região de Dourados, MS. 2.ed. Embrapa Agropecuária Oeste. 32p.

Hargreaves GH, Samani ZA (1985). Reference crop evapotranspiration from ambient air temperature. American Society of Agricultural and Biological Engineers Meeteng. (Paper 85 -2517).
Palaretti LF, Mantovani EC, Sediyama GC (2014). Comparação entre métodos de estimativa da evapotranspiração de referência $\left(E T_{0}\right)$ em regiões citrícolas paulistas. Engenharia Agrícola 34:38-47.

Pereira AR, Angelocci LR, Sentelhas PC (2002). Agrometeorologia: Fundamentos e aplicações práticas. Livraria e Editora Agropecuária. 478p.

Pereira AR, Villa Nova NA, Sediyama GC (1997). Evapotranspiração. FEALQ. 183p.

Priestley CHB, Taylor RJ (1972). On the assessment of surface heat flux on evaporation using large-scale parameters. Monthly Weather Review 100:81-92.

Souza JM, Pereira LR, Rafael AM, Silva LD, Reis EF, Bonomo R (2014). Comparison of methods for estimating reference evapotranspiration in two locations of Espirito Santo. Revista Brasileira de Agricultura Irrigada 8:114-126.

Tanaka AA, Souza AP, Klar AE, Silva AC, Gomes AWA (2016). Evapotranspiração de referência estimada por modelos simplificados para o Estado do Mato Grosso. Pesquisa agropecuária brasileira 51:91104.

Willmott CJ, Ackleson SG, Davis JJ, Feddema K, Klink DR (1985). Statistics for the evaluation and comparison of models. Journal of Geophysical Research 90:8995- -9005. 